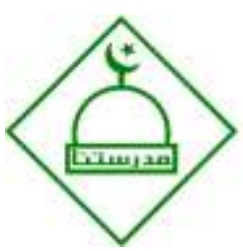

\title{
Hubungan Efektivitas Pembelajaran Sistem Guru Keliling dengan Motivasi Belajar Siswa di Masa Pandemi Covid 19
}

\author{
Widiyanti Nur Hasanah, Hilman Mangkuwibawa, Sani Insan Muhamadi \\ Program Studi Pendidikan Guru Madrasah Ibtidaiyah Universitas Islam Negeri Sunan Gunung \\ Djati Bandung, Indonesia \\ widiyantinurhasanah56482@gmail.com,hilmanmangkuwibawa.eknows@gmail.com, \\ saniinsanmuhamadi@uinsgd.ac.id
}

\begin{abstract}
ABSTRAK
Penelitian ini dilatar belakangi karena adanya perubahan sistem pembelajaran sebagai dampak dari adanya pandemi Covid 19. Pembelajaran di SD Dharma Ibu dilakukan dengan menerapkan sistem guru keliling. Sistem guru keliling ini salah satu pembelajaran luar jaringan yang dalam pelaksanaannya yang sama sekali tidak terhubung jaringan network. Dengan diterapkannya sistem guru keliling, diharapkan dapat meningkatkan motivasi belajar siswa. Penelitian ini didasari atas suatu asumsi bahwa munculnya motivasi belajar yang tinggi ditentukan oleh proses pembelajaran yang efektif. Sementara itu proses pembelajaran yang efektif bergantung dari situasi lingkungan yang kondusif serta sistem pembelajaran yang dipilih. Metode penelitian menggunakan metode korelasional dengan pendekatan kuantitatif. Teknik penelitian menggunakan prohability sampling yaitu dengan memberikan peluang yang sama untuk seluruh siswa kelas IV. Data dikumpulkan menggunakan teknik angket yang sebelumnya sudah dilakukan uji validitas dan uji reliabilitasnya. Sedangkan untuk analisis data, menggunakan teknik korelasi Product-Moment yang teknik perhitungannya menggunakan program Kolmogorov-Smirnov SPSS versi 26. Hasil penelitian yang menunjukkan bahwa: 1) efektivitas pembelajaran sistem guru keliling dalam pembelajaran di masa pandemi covid 19 berada pada kategori tinggi dengan presentase $66,7 \%$ dan hasil rata-rata jawaban sebesar 66;2) motivasi belajar siswa di kelas IV SD Dharma Ibu di masa pandemi covid 19 berada pada kategori tinggi dengan presentase 53,2\% dan hasil rata-rata jawaban sebesar 78,22; 3) hubungan efektivitas pembelajaran menggunakan sistem guru keliling dengan motivasi belajar siswa di kelas IV SD Dharma Ibu memperoleh hasil 0,652 yang berada pada kategori tinggi.
\end{abstract}

Kata-kata Kunci: Efektivitas Pembelajaran, Motivasi Belajar, Masa Pandemi Covid 19

\section{Relationship of The Effectiveness of Learning Of Mobile Teacher Systems and Student Learning Motivation in the Covid 19 Pandemic}

\begin{abstract}
This research was motivated by changes in the learning system as a result of the Covid 19 pandemic. Learning at Dharma Ibu Elementary School is done by applying a mobile teacher system. This mobile teacher system is one of the learning outside the network that in its implementation is not network connected at all. With the implementation of the mobile teacher system, it is expected to increase students' learning motivation. This research is based on an assumption that the emergence of high learning motivation is determined by an effective learning process. Meanwhile, an effective learning process depends on a conducive environmental situation and a selected learning system. The research method uses a correlational method with a quantitative approach. The research technique uses prohability sampling, namely by providing equal opportunities to all fourth grade students. Data collection uses a questionnaire technique that has previously been tested for validity and reliability tests. As for data analysis, using the Product-Moment correlation technique whose calculation technique uses the Kolmogorov-Smirnov SPSS version
\end{abstract}


26 program. The results showed that: 1) the effectiveness of the mobile teacher system learing in learning during the covid 19 pandemic was in the high category with a percentage of 66,7\% and a average answer of 66; 2) the learning motivation of fourth grade students of SD Dharma Ibu during the covid 19 pandemic was in the high category with a percentage of $53,2 \%$ and an avarage answer of 78,$22 ; 3)$ the relationship between the effectiveness of learning using a mobile teacher system and the learning motivation of fourth grade students at SD Dharma Ibu obtained 0,652 results which are included in the bigh category.

Keywords: learning effectiveness; motivation to learn; covid 19 pandemic period

\section{PENDAHULUAN}

Banyak orang yang terpapar virus corona, sehingga mendesak pemerintah Republik Indonesia untuk mengambil kebijakan. Kebijakan dari pemerintah ini dikeluarkan karena pendidikan tidak bisa dilakukan tatap muka dan pembelajaran dilakukan di rumah dengan sistem daring/online. Pada saat proses pembelajaran daring/online berlangsung guru sering menemukan beberapa kendala yang terjadi baik dalam pembelajaran maupun siswa itu sendiri. Masalah yang sering kali muncul yaitu menurunnya semangat siswa untuk belajar serta rendahnya penurunan motivasi belajar anak.

Maka dari itu, Kepala Sekolah SD Dharma Ibu memberlakukan pembelajaran luar jaringan dengan diterapkannya sistem guru keliling dalam pembelajaran. Sistem guru keliling adalah salah satu pembelajaran luring/luar jaringan. Sistem guru keliling ini dilakukan tatap muka, dimana guru berkeliling ke rumah siswa (bergantian) untuk mengajarkan ilmu pengetahuan sesuai dengan protokol kesehatan. Dengan diberlakukan pembelajaran menggunakan sistem guru keliling diharapkan pembelajaran dapat efektif serta dapat membantu meningkatkan motivasi belajar siswa di tengah pandemi ini.

Efektivitas pembelajaran adalah suatu keadaan yang menunjukkan sejauh mana hasil guna yang diperoleh setelah pelaksanaan proses belajar mengajar. Menurut Trianto (dalam Lubis,2017) menyebutkan bahwa keefektifan pembelajaran adalah hasil guna yang diperoleh setelah pelaksanaan proses belajar mengajar. Dapat juga dikatakan efektif apabila tingkat pencapaian tujuan tercapai. Dapat dikatakan pula, bahwa efektivitas pembelajaran merupakan suatu standar yang digunakan untuk mencapai tujuan pembelajaran dengan memperhatikanindikator yang telah disusun. Adapun indikator efektivitas pembelajaran menurut Slavin (2009) adalah sebagai berikut : (1) Mutu pengajaran, (2) Tingkat pengajaran yang tepat, (3) Insentif, dan (4) Waktu. Dengan diterapkannya sistem guru keliling, diharapkan meningkatnya motivasi belajar siswa.

Motivasi belajar dalam diri seseorang akan menimbulkan gairah atau meningkatkan semangat dalam belajar. Motivasi belajar mengandung usaha untuk mencapai tujuan belajar yaitu pemahaman materi dan pengembangan belajar. Motivasi belajar adalah faktor pendukung yang dapat mengoptimalkan kecerdasan siswa dalam meraih prestasi dan hasil belajar. 
Sardiman (2011) motivasi belajar adalah keseluruhan daya penggerak di dalam diri peserta didik yang menimbulkan kegiatan belajar, yang menjamin kelangsungan dari kegiatan belajar dan yang memberikan arah pada kegiatan belajar, sehingga tujuan yang dikehendaki oleh subjek belajar dapat tercapai. Adapun menurut Uno (2016), indikator motivasi belajar adalah sebagai berikut : (1) Adanya hasrat dan keinginan berhasil, (2) Adanya dorongan dan kebutuhan dalam belajar, (3) Adanya harapan dan cita- cita masa depan, (4) Adanya penghargaan dalam belajar, (5) Adanya kegiatan menarik dalam belajar, (6) Adanya lingkungan kondusif sehingga memungkinkan siswa dapat belajar.

Berdasarkan fakta di lapangan bahwa semangat siswa untuk belajar masih minim dapat terlihat dari masih sedikitnya siswa yang mengumpulkan tugas sekolahnya, tidak semua orang mengikuti pembelajaran, dan tidak efektifnya pembelajaran di rumah. Dari permasalahan yang sudah dijelaskan diatas, maka penulis melakukan penelitian korelasional yang berjudul "Hubungan Efektivitas Pembelajaran Sistem Guru Keliling Dengan Motivasi Belajar Siswa Di Masa Pandemi Covid 19 (Penelitian Korelasional Di Kelas IV SD Dharma Ibu Bogor".

Adapun rumusan masalah dalam penelitian ini adalah (1) Bagaimana efektivitas pembelajaran sistem guru keliling dalam pembelajaran di masa pandemi covid 19 ?, (2) Bagaimana motivasi belajar siswa di kelas IV SD Dharma Ibu Bogor di masa pandemi covid 19 ?, (3) Bagaimana hubungan efektivitas pembelajaran menggunakan sistem guru keliling dengan motivasi belajar siswa di kelas IV SD Dharma Ibu Bogor?.

Adapun tujuan penelitian ini adalah (1) Untuk mengetahui efektivitas pembelajaran sistem guru kelilingdalam pembelajaran di masa pandemi covid 19, (2) Untuk mengetahui motivasi belajar siswa di kelas IV SD Dharma Ibu Bogor di masa pandemi covid 19, (3) Untuk mengetahui hubungan efektivitas pembelajaran menggunakan sistem guru keliling dengan motivasi belajar siswa dikelas IV SD Dharma Ibu Bogor.

Menurut Limbong (2020) efektivitas adalah suatu ukuran yang menerangkan sejauh mana sasaran yang telah ditentukan dapat tercapai. Semakin tinggi presentase sasaran yang dicapai, maka efektivitasnya semakin tinggi pula. Pembelajaran merupakan suatu proses yang dialami oleh peserta didik di sekolah/lingkungan/ masyarakat. Karena belajar merupakan perubahan tingkah laku, maka diperlukan pembelajaran yang bermutu atau efektif agar dapat mencerdaskan peserta didik itu sendiri. Belajar salah satu bentuk perilaku yang sangat penting bagi kehidupan manusia. Karena dengan belajar, maka akan membantu manusia untuk menyesuaikan diri (adaptasi) dengan lingkungannya. Jadi, efektivitas pembelajaran adalah suatu keadaan yang menunjukkan sejauh mana hasil guna yang diperoleh setelah pelaksanaan proses belajar mengajar. 
Sistem adalah sekumpulan komponen yang saling berintegrasi dan saling bekerja sama untuk mencapai tujuan tertentu. Adapun fungsi sistem yang utama adalah menerima masukan, mengolah masukan, dan menghasilkan masukan. Kata guru keliling memiliki arti guru berkeliling ke rumah siswa untuk mengajarkan materi pembelajaran. Guru keliling dilakukan dengan cara kunjungan guru ke rumah anak didik dengan mengumpulkan siswa yang tempat tinggalnya berdekatan.

Guru keliling dilaksanakan seminggu sekali atau dua kali. Jadi, sistem guru keliling adalah guru memberikan ilmu pengetahuan dengan cara mengumpulkan anak di rumah salah satu siswa, untuk mengajarkan ilmu pengetahuan sesuai dengan protokol kesehatan. Adapun langkah-langkah pelaksanaan sistem guru keliling adalah sebagai berikut: (1) pembagian siswa ke dalam dua kelompok berdasarkan tempat tinggalnya. (2) penentuan tempat berlangsungnya pembelajaran dengan menerapkan sistem guru keliling. (3) penentuan waktu berlangsungnya pembelajaran dengan menerapkan sistem guru keliling.

Menurut Cleopatra (2015) Motivasi adalah hasrat, dorongan dan kebutuhan seseorang untuk dapat melakukan aktivitas tertentu. Sehingga motivasi diartikan sebagai kekuatan yang mendorong tindakan menuju suatu tujuan. Belajar adalah perubahan tingkah laku secara relatif permanen dan secara potensial terjadi sebagai hasil dari praktik atau penguatan (reinforced practice) yang dilandasi untuk mencapai tujuan tertentu. Jadi, motivasi belajar adalah sebuah penggerak atau pendorong yang membuat seseorang akan tertarik pada belajar sehingga akan belajar secara terus menerus.

Motivasi belajar dapat dirangsang dengan memberikan penghargaan kepada anak, lingkungan belajar yang kondusif, dan kegiatan belajar yang menarik. Menurut Sardiman (2011) motivasi belajar adalah keseluruhan daya penggerak di dalam diri peserta didik yang menimbulkan kegiatan belajar, yang menjamin kelangsungan dari kegiatan belajar dan yang memberikan arah pada kegiatan belajar, sehingga tujuan yang dikehendaki oleh subjek belajar dapat tercapai.

\section{METODE PENELITIAN}

Penelitian ini menggunakan pendekatan kuantitatif dengan metode penelitian menggunakan korelasional. Yang dimana penelitian ini bertujuan untuk menelaah dan menganalisis variasi dalam variabel berhubungan dengan variabel lain, yang tentunya berlandaskan dari koefisien korelasi yang sejalan dengan pendapat (Azwar, 2010).

Data dikumpulkan menggunakan teknik angket yang sebelumnya sudah dilakukan uji validitas dan uji reliabilitasnya. Angket yang digunakan berupa pernyataan tertulis untuk menggali data dari siswa sehingga memperoleh informasi mengenai hubungan efektivitas pembelajaran sistem guru keliling dengan motivsai belajar siswa di masa pandemi covid 19. Angket yang digunakan adalah angket tertutup, yang dimana reponden dapat memilih salah satu dari beberapa 
kemungkinan jawaban yang telah disediakan. Skala yang digunakannya adalah skala likert. Jawaban dari setiap item instrumen yang menggunakan skala likert berupa pernyataan positif ataupun pernyataan negatif yang terdiri dari empat kategori skala, yaitu Sangat Sering (SR), KadangKadang (KK), Jarang (JR), Tidak Pernah (TP). Setiap kategori memiliki bobot yang berbeda-beda sesuai dengan jawaban siswa. Pembobotan setiap item dijabarkan pada tabel berikut ini

Tabel 1 Interprestasi Skala Angket

\begin{tabular}{|c|c|c|}
\hline Skala & Positif & Negatif \\
\hline Sangat Sering & 4 & 1 \\
\hline Kadang-kadang & 3 & 2 \\
\hline Jarang & 2 & 3 \\
\hline Tidak Pernah & 1 & 4 \\
\hline
\end{tabular}

Populasi penelitian ini diajukan kepada seluruh siswa kelas IV Sekolah Dasar Dharma Ibu tahun ajaran 2020/2021 yang berjumlah 30 orang dengan menggunakan teknik prohability sampling. Sedangkan untuk analisis data yang digunakan dalam penelitian ini, menggunakan teknik korelasi Product-Moment yang teknik perhitungannya menggunakan program Kolmogorov-Smirnov SPSS versi 26. Waktu penelitian ini dilakukan dari bulan Desember 2020 sampai dengan bulan Juli 2021.

\section{HASIL DAN PEMBAHASAN}

Berdasarkan data angket yang telah diolah menggunakan bantuan software Statistical Product and Solution Services (SPSS) versi 26 pada variabel efektivitas pembelajaran sistem guru keliling (Variabel X) dapat diketahui yang memperoleh skor tertinggi sebesar 76 dan skor terendah 53 . Dengan hasil mean 66 dan standar deviasi yaitu 5,84. Simpangan data inidikatakan baik karena standar deviasi lebih kecil dari mean yaitu $5,84<66$.

Dari hasil data angket yang telah diketahui diatas, peneliti mengukur efektivitas pembelajaran sistem guru keliling di kelas IV SD Dharma Ibu yang memperoleh hasil yang berada pada kategori sangat tinggi yang berjumlah 18 siswa dengan presentase 60\%, sedangkan efektivitas pembelajaran sistem guru keliling pada kategori tinggi berjumlah 12 siswa dengan presentase 40\%. Maka, dapat dikatakan bahwa efektivitas pembelajaran dengan menggunakan sistem guru keliling di SD Dharma Ibu Bogor mayoritas berada pada kategori sangat tinggi. 


\section{Efektivitas Pembelajaran Sistem Guru Keliling}

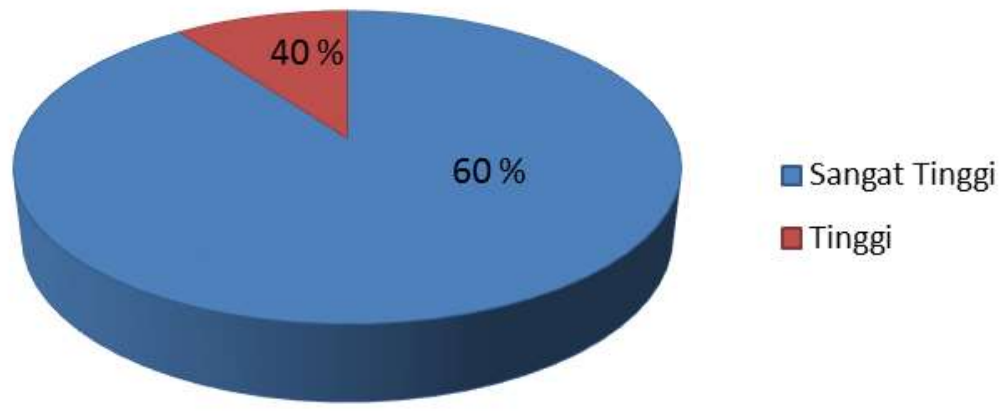

Gambar 1 Diagram Presentase Efektivitas Pembelajaran

Sedangkan data angket pada variabel motivasi belajar siswa di masa pandemi covid 19 (Variabel Y) memperoleh skor tertinggi 95 dan skor terendah 61. Dengan hasil mean 78,22 dan standar deviasi 9,15. Simpangan data ini dikatakan baik karena stadar deviasi lebih kecil dari mean, yaitu 9,15 $<78,22$. Dari hasil data angket yang telah diketahui diatas, peneliti mengukur motivasi belajar siswa di masa pandemi covid 19 kelas IV SD Dharma Ibu Bogor yang berada pada kategori sangat tinggi berjumlah 7 orang dengan presentase 23,4\%, sedangkan motivasi belajar siswa di masa pandemi covid 19 pada kategori tinggi berjumlah 16 orang dengan presentase 53,2\%, dan motivasi belajar siswa di masa pandemi covid 19 pada kategori cukup berjumlah 7 orang dengan presentase 23,4\%. Maka, dapat dikatakan bahwa motivasi belajar siswa di masa pandemi covid 19 pada kelas IV SD Dharma Ibu Bogor mayoritas berada pada kategori tinggi.

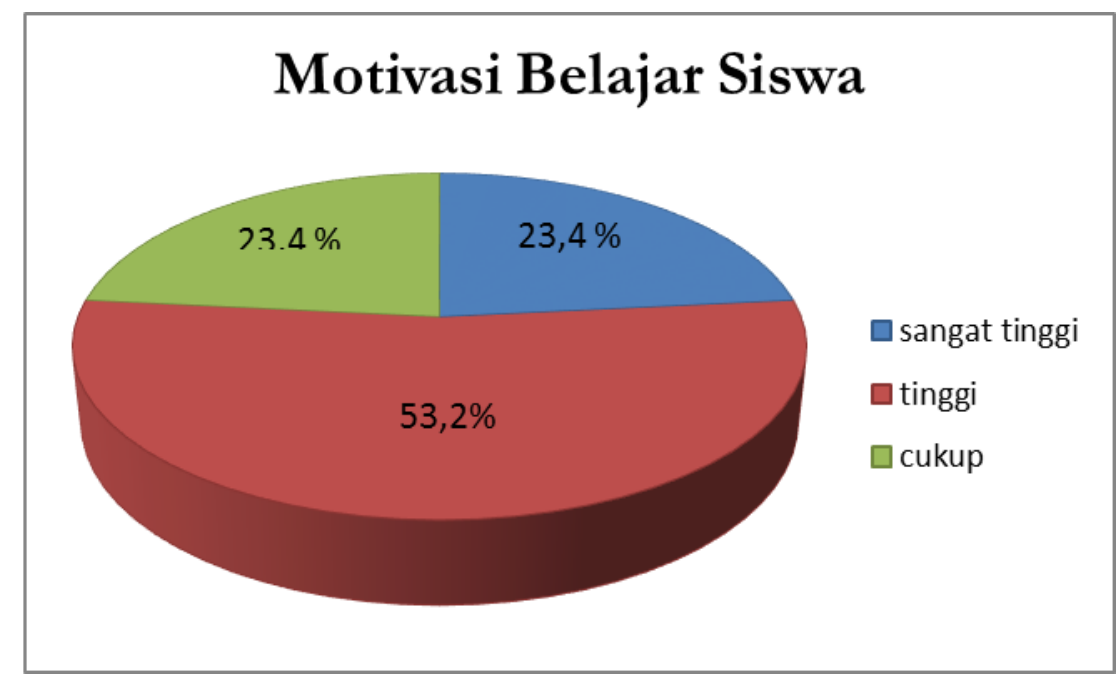

Gambar 2 Diagram Presentase Motivasi Belajar Siswa

Hasil analisis korelasi antara efektivitas pembelajaran sistem guru keliling dengan motivasi belajar siswa di masa pandemi covid 19 menunjukkan adanya korelasi yang positif yaitu sebesar 0,652 dengan taraf signifikasi sebasar 5\% (0,05). Berdasarkan hasil perhitungan uji korelasi antara 
variabel $\mathrm{X}$ dan variabel $\mathrm{Y}$ diperoleh hasil sebesar 0,652 dengan signifikasi 0,000. Responden 30 orang maka $\mathrm{r}$ tabel 0,349. Jadi, $\mathrm{r}_{\text {hitung }}>\mathrm{r}_{\text {tabel }}=0,652>0,349$. Maka, dapat dikatakan bahwa terdapat hubungan antara efektivitas pembelajaran sistem guru keliling dengan motivasi belajar siswa di masa pandemi covid 19. Derajat hubungan ini memiliki korelasi yang tinggi.

Sesuai dengan teori Sugiyono (2013) bahwa apabila korelasi sebesar 0,60 - 0,79 termasuk ke dalam kualifikasi tinggi. Jadi, dapat dikatakan apabila semakin tinggi efektivitas pembelajaran sistem guru keliling maka semakin tinggi juga motivasi belajar siswa. Dan begitu sebaliknya apabila semakin rendah efektivitas pembelajaran sistem guru keliling maka semakin rendah juga motivasi belajar siswa. Sejalan dengan pendapat Astuti (2017) koefisien korelasi positif menunjukkan keeretan hubungan antara variabel $\mathrm{X}$ dan variabel $\mathrm{Y}$ yang searah. Hal ini berarti bahwa semakin meningkatnya nilai variabel X maka nilai dari variabel Y akan semakin meningkat. Dan sebaliknya semakin rendah nilai variabel $\mathrm{X}$ maka nilai dari variabel $\mathrm{Y}$ akan semakin rendah.

\section{SIMPULAN}

Berdasarkan hasil penelitian mengenai efektivitas pembelajaran dengan motivasi belajar siswa dapat disimpulkan sebagai berikut : (1) Efektivitas pembelajaran sistem guru keliling dalam pembelajaran di masa pandemi covid 19 didapat dari hasil rata-rata jawaban efektivitas pembelajaran sistem guru keliling kelas IV SD Dharma Ibu Bogor ialah sebesar 66. Jadi, dapat dikatakan bahwa efektivitas pembelajaran cukup baik. Setiap siswa dalam pembelajaran sistem guru keliling ini dapat meningkatkan pengetahuan, keterampilan dan sikap sehingga tujuan pembelajaran sistem guru keliling ini tercapai. (2) Motivasi belajar siswa di kelas IV SD Dharma Ibu Bogor di masa pandemi covid 19 didapat dari hasil rata-rata jawaban motivasibelajar siswa di masa pandemi covid 19 kelas IV SD Dharma Ibu Bogor ialah sebesar 78,22. Jadi, dapat dikatakan bahwa motivasi belajar baik. Setiap siswa harus memiliki motivasi belajar agar tujuan belajar tercapai yaitu pemahaman materi dan pengembangan belajar. (3) Hubungan efektivitas pembelajaran menggunakan sistem sistemguru keliling dengan motivasi belajar siswa di kelas IV SD DharmaIbu Bogor tergolong kategori tinggi. Dapat dilihat bahwa dari hasil perhitungan uji korelasi antara variabel $\mathrm{X}$ dan variabel $\mathrm{Y}$ sebesar 0,652 dengan signifikan 0,000. Responden 30 orang, maka $\mathrm{r}$ tabel 0,349. Jadi, $\mathbf{r}_{\text {hitung }}>\mathbf{r}_{\text {tabel. }}$ Maka, dapat dikatakan bahwa terdapat hubungan antara efektivitas pembelajaran sistem guru keliling dengan motivasi belajar siswa di masa pandemi covid 19. 


\section{DAFTAR PUSTAKA}

Astuti, C. C. (2017). Analisis Korelasi untuk Mengetahui Keeratan Hubungan antara Keaktifan Mahasiswa dengan Hasil Belajar Akhir. Jurnal Umsida.

Azwar, S. (2010). Metode Penelitian. Yogyakarta: Pustaka Pelajar.

Cleopatra, M. (2015). Pengaruh Gaya Hidup dan Motivasi Belajar Terhadap Presatsi Belajar Matematika. Jurnal Pendidikan MIPA.

Limbong T., \&. S. (t.thn.). Menemukan Mata Kuliah yang Efektif Belajar Daring (Belajar dan Ujian) dengan Metode Multi-Attribute Utility Theory (MAUT). Resti, Vol.4, No.2, 370-376.

Lubis, R. (2017). Efektivitas Model Pembelajaran Grasha-Riechman Terhadap Prestasi Belajar Matematika. Seminar Nasional Matematika dan Aplikasi.

Sardiman. (2011). Interaksi dan Motivasi Belajar Mengajar. Jakarta: Rajawali Press.

Sugiyono. (2013). Metode Penelitian Kualitatif, Kuantitatif dan R\&DD. Bandung: Alfabeta.

Uno, H. B. (2016). Teori Motivasi dan Pengukurannya: Analisis di Bidang Pendidikan. Jakarta: Bumi Aksara. 